\title{
Tembang Anak Jawa sebagai Media Pembelajaran Membaca
}

\author{
Budi Raharja ${ }^{1}$ \\ ${ }^{1}$ Prodi Pendidikan Seni Pertunjukan, Fakultas Seni Pertunjukan, Institut Seni Indonesia Yogyakarta
}

\begin{abstract}
Javanese Children's Songs as a Learning Model to Read. The reason for conducting this research is that the reading ability of Indonesian children at the global level is still low. It indicates that the goal of realizing a generation of nations that can compete globally is still far from being a reality. The writer wants to solve the problem by optimizing reading learning at the Kindergarten education level because this period is the golden age of optimizing human abilities, including reading skills. The writer created a learning model for early childhood reading based on Javanese local wisdom using children's traditional songs. The study used the development research methods (designing the model, testing, and reporting the results). The design of the learning model using songs on how to memorize letters, remember letter shapes, read vowels, learn spelling and enrichment was recorded in the form of videos sent to students' parents to study and then teach to their children. In addition, parents were asked to answer a questionnaire about implementing the learning and videos, which were also uploaded on the YouTube channel to get public feedback. The questionnaire was used to get feedback from students' parents while community responses were submitted through the facilities provided by YouTube. The research results show that the children's song-based of a reading learning model for early childhood during the pandemic has strengths and weaknesses. The model's strengths are encouraging learning to read and giving a fun learning atmosphere. Meanwhile, the drawbacks are that learning activity is not optimal because the parents should go to work and not all master children's songs. The language of instruction uses mixed language models. These weaknesses can be overcome by face-to-face learning and changing the language of instruction to Javanese.
\end{abstract}

Keywords: children's song; learning to read; online learning

\begin{abstract}
ABSTRAK
Alasan dilakukan penelitian ini adalah kemampuan membaca anak Indonesia di tingkat dunia rendah. Hal ini mengindikasikan cita-cita mewujudkan generasi bangsa yang dapat bersaing secara global masih jauh dari kenyataan. Penulis ingin membantu memecahkan permasalahan tersebut dengan mengoptimalkan pembelajaran membaca di jenjang pendidikan Taman Kanak-kanak dengan alasan masa tersebut adalah masa usia emas mengoptimalkan kemampuan manusia, termasuk di dalamnya kemampuan membaca. Peneliti akan membuat model pembelajaran membaca anak usia dini berbasis kearifan lokal Jawa, menggunakan tembang dolanan anak. Metode penelitian pengembangan (merancang model, menguji, dan melaporkan hasilnya) digunakan dalam penelitian ini. Rancangan model pembelajaran menggunakan tembang cara menghafal huruf, cara mengingat bentuk huruf, cara membaca huruf hidup, cara belajar mengeja dan pengayaan direkam dalam bentuk video dikirimkan ke orang tua siswa untuk dipelajari kemudian diajarkan kepada anaknya. Selain itu orang tua diminta menjawab kuesioner tentang pelaksanaan pembelajaran tersebut dan video juga diungggah dalam kanal youtube untuk mendapatkan tanggapan masyarakat. Kuesioner digunakan untuk mendapatkan tanggapan orang tua siswa sedangkan tanggapan masyarakat disampaikan melalui fasilitas yang disediakan YouTube. Hasilnya model pembelajaran membaca berbasis tembang anak untuk anak usia dini di masa pandemi mempunyai kekuatan dan kelemahan. Kekuatannya model dapat mendorong belajar membaca, suasana belajar menyenangkan; sedangkan kekurangannya pembelajaran belum optimal karena orang tua bekerja dan tidak semua dari mereka menguasai tembang anak serta bahasa pengantar model menggunakan bahasa campuran. Kelemahan tersebut dapat diatasi dengan pembelajaran tatap muka dan mengganti bahasa pengantarnya bahasa Jawa semuanya.
\end{abstract}

Kata kunci: tembang anak; belajar membaca; pembelajaran daring

1 Alamat korespondensi: Prodi Pendidikan Seni Pertunjukan, Fakultas Seni Pertunjukan, Institut Seni Indonesia Yogyakarta, Jalan Parangtritis Km. 6.5 Yogyakarta. E-mail: budiraharja51@gmail.com; HP.: 089668912544. 


\section{Pendahuluan}

Kemampuan membaca anak Indonesia di tingkat internasinal rendah. Pada tahun 2018 menduduki ranking 74 dari 79 negara yang berpartisipasi. Hal itu mengindikasikan bahwa kualitas sumber daya manusia kita perlu ditingkatkan agar dapat bersaing di tingkat global (Hewi \& Shaleh, 2020). Penelitian ini ingin membantu memecahkan permasalahan tersebut dengan mengoptimalkan proses pembelajaran membaca di jenjang pendidikan Taman Kanakkanak. Optimalisasi dilakukan dengan membuat model pembelajaran berbasis tembang anak sebagai pelengkap model pembelajaran membaca yang sudah ada. Model ini efektif karena pembelajaran membaca yang menggunakan irama lebih efektif dibanding tanpa irama.

Pembelajaran dolanan anak, yang di dalamnya terdapat tembang-tembang anak, mengandung aspek-aspek pengembangan fisik motorik, kognitif, bahasa, seni, dan sosial emosional anak (Raharja, 2021). Bahkan dolanan Jawa tersebut dapat membantu pembentukan karakter anak usia dini. dengan cara menggali nilai-nilai kehidupan dari makna pada lirik lagu dolanan berupa nilai pendidikan, pengetahuan, religius, sosial, dan budaya (Rosmiati, 2014).

Secara teoritis musik dapat memfasilitasi belajar bahasa. Hal itu karena ritme musik, pola kalimat dalam lirik lagu membantu siswa memahami dan menyimaknya secara seksama apabila penggunaannya mempertimbangkan perkembangan psikologi anak. Pembelajaran melalui musik untuk anak usia dini sampai sekolah dasar dengan bermusik, bernyanyi, menggambar dan bergerak dapat membentuk "peta belajar" siswa. Mengikuti alunan musik dan menginterpretasi lagu, dapat membentuk suasana menyenangkan dalam melakukan pembelajaran (Bakar, 2016).

Musik dapat menciptakan suasana yang memancing anak berkomunikasi secara tidak disadari, menjadikan komunikasi lebih intensif, anak lebih peka terhadap isyarat non-verbal dan gerakan ekspresif, serta dapat membantu mengembangkan perbendaharaan kata melalui bernyanyi, maupun meningkatkan koordinasi ekspresif (Simpson \& Keen, 2011) (Thompson \& Mcferran, 2015) (Drossinou-korea \& Fragkouli, 2016). Bermain musik juga dapat meningkatkan keterampilan dan respons emosionalnya serta kemampuan belajar dan berpikir anak (Constantin, 2015).

Pemanfaatan media audio berbasis lagu memotivasi belajar karena melalui lagu pembelajaran menjadi menyenangkan, menarik, dan materi lebih mudah dipahami (Ratminingsih, 2016). Musik atau lagu dapat menciptakan suasana ramah ketika siswa mulai proses pembelajaran, meningkatkan minat belajar siswa, meningkatkan daya ingat, menjadikan suasana lebih relaks dan konsentrasi penuh serta meningkatkan kemampuan kebahasaannya (Retnoningsih, 2019).

Model pembelajaran membaca bagi anak usia dini yang menggunakan musik merupakan model pembelajaran efektif pada saat ini. Hasil penelitian berjudul "mengusik" atau model pembelajaran mengeja menggunakan musik bagi pembaca pemula di jenjang pendidikan dasar (Sekolah Dasar) efektif untuk meningkatkan kemampuan membaca anak. Model tersebut mengelompokkan siswa ke dalam empat kelompok: (a) Siswa dengan kemampuan awal membaca 1 sampai 2 suku kata (ma, pa; makan, roti); (b) Siswa dengan kemampuan awal membaca 3 suku kata (budaya, siapa); (c) Siswa dengan kemampuan membaca bunyi sengau "ng" (sedang, radang); dan (d) Siswa dengan kemampuan membaca perpaduan 2 huruf konsonan. Dalam belajar masing-masing kelompok diberi latihan mengeja menggunakan lagu atau melodi yang mereka kuasai (Munawaroh Epriliani Aminah \& Nisa, 2016).

Pembelajaran membaca jenjang pendidikan prasekolah dapat dilakukan melalui tahapan membaca dan menulis. Tahap membaca meliputi memahami dan mengucapkan huruf, menuliskan kesadaran fonemik, menerapkan langsung ke bentuk kata, dan menerapkan langsung ke ejaan silabus, kata, dan frase; sedangkan pembelajaran menulis melalui menghafal huruf, mengidentifikasi bentuk huruf, membaca cerita, latihan mengeja, membaca buku, dan menampilkan media. Bentuk inisiasi bahasa tertulis melalui mulai dari pengenalan huruf ke huruf, inisiasi silabus dan kata, 
serta keterlibatan anak. Terakhir memotivasi anak, guru menganalisis dan mencari solusi di alam, metodis, dan strategis (Musfiroh, 2007).

Diskusi di atas memberi gambaran bahwa pembelajaran literasi prasekolah diawali dengan mengenal bentuk huruf, mengucapkannya, merangkai menjadi kata atau frase. Penulis akan menerapkan model pembelajaran tersebut pada pembelajaran membaca di TK Pertiwi 3 Sinduadi. Caranya kebiasaan pembelajaran di sekolah tersebut dinarasikan dan dijadikan syair tembang kemudian dijadikan media pembelajaran membaca tersebut. Media pembelajaran membaca menggunakan tembang ini lebih efektif karena belajar menggunakan irama lebih mudah dibanding belajar membacara tanpa irama.

Pembelajaran diawali menghafal huruf, mengenal bentuk huruf, belajar membaca huruf hidup, belajar mengeja, dan pengayaan. Belajar menghafal huruf menggunakan tembang $A B C$, mengenal bentuk dengan cara menganalogikan bentuk geometri untuk menghafal bentuk huruf (garis lurus duwe bathuk atau garis lurus punya dahi untuk menghafal bentuk huruf P), cara membaca huruf hidup dengan cara melafalkan bentuk bibir ketika mengucapkannnya (cara membaca I meringis, cara membaca $\mathrm{O}$ mlongo), belajar mengeja dengan melafalkan cara menggabung dua huruf (P karo A PA), dan memperkaya perbedaharaan kata dengan menampilkan gambar (binatang atau barang) kemudian ditembangkan (menampilkan gambar kereta api kemudian nembang Sepur Klutuk), menampilkan gambar gajah kemudian anak diajak nembang Gajah-gajah.

Pembelajaran membaca di taman kanakkanak lebih efektif apabila pertama dilakukan dalam suasana bermain, karena dengan cara tersebut anak tidak bosan dan secara tidak sadar telah belajar membaca (Istiyani, 2014). Kedua pembelajaran dalam kondisi yang menyenangkan dapat meningkatkan minat membaca anak; karena dalam suasana senang anak terpacu belajar membaca (Yuliatun, 2018). Ketiga menggunakan multimedia (membaca huruf, kata-kata dan kalimat sederhana) lebih menarik (Tjoe, 2013); sedangkan penggunaannya secara tepat, kreatif dan inovatif, serta pemilihan materi yang sesuai merupakan aspek pendukungnya (Yulia, 2013), Keempat metode membaca sebuah kata yang terdiri dari dua suku kata terlebih dahulu, kemudian dilanjutkan dengan kata yang memiliki lebih dari dua suku kata. (Indria, Sumarsih, \& Agustriana, 2017). Kelima musik dapat memudahkan anak dalam memahami materi ajar yang disampaikan; anak senang, tidak bosan, dan tertarik dalam mengikuti proses pembelajaran (Miranti, Engliana, \& Hapsari, 2015).

Belajar menulis akan efektif apabila melalui tahapan membaca dan tulisan membentuk dan mengucapkan huruf, menuliskan fonemik, menerapkan langsung ke bentuk kata, dan menerapkan langsung ke ejaan silabus, kata, dan frase. Proses reseptif bahasa tertulis melalui menghafal alfabeta, mengidentifikasi bentuk huruf, membaca cerita, latihan mengeja, instruksi membaca buku, dan menampilkan media; sedangkan inisiasi bahasa tertulis dapat dicapai melalui berbagai cara inisiasi dari huruf ke huruf, inisiasi silabus dan kata, serta keterlibatan anak. memotivasi anak, guru menganalisis dan mencari solusi yang matang di alam, metodis, dan strategis (Musfiroh, 2007)

Pembelajaran Anak Usia Dini (PAUD) selama pandemi Covid-19 ini mengikuti aturan berikut. Pertama tidak memberikan tugas yang bermacammacam. Anak-anak diberikan keleluasan bermain di rumah dengan bimbingan dan pengawasan orang tua; sedangkan Dinas Pendidikan berperan aktif memberikan support kepada guru dan orang tua murid; mengambil langkah-langkah inovatif, memberikan solusi atas permasalahan yang terjadi serta mempertimbangkan cara-cara yang lebih baik. Setiap institusi PAUD bisa memberikan biaya kuota penggunaan internet agar tidak membebani guru untuk biaya kuota; memanfaatkan teknologi informasi untuk proses belajar mengajar, memiliki aplikasi digital yang bisa diakses oleh seluruh pendidik, anak didik maupun orang tua siswa. Kebijakan belajar di rumah, membuat para guru, termasuk di jenjang PAUD, diharapkan segera beradaptasi; pembelajaran yang biasanya dilakukan secara tatap muka di sekolah, kini harus dilakukan secara jarak jauh dengan mempergunakan teknologi komunikasi. Platform pembelajaran 
baru ini mengharuskan guru PAUD memiliki kemampuan dan keterampilan mengoperasikan teknologi, merencanakan pembelajaran jarak jauh yang menyenangkan dan sesuai dengan kurikulum pendidikan (Pramana, 2020).

Pembelajaran di masa pandemi jenjang pendidikan Prasekolah atau Taman kanak-kanak sebagian besar menggunkan metode campuran antara pembelajaran di luar jaringan (luring) dan pembelajaran dalam jaringan (daring). Pembelajaran daring menggunakan sosial media WhatsApp (WA) Grup (pesan teks dan telepon), Zoom, media lain (tayangan televisi); sedangkan pembelajaran luring dilakukan dengan kunjungan dari rumah ke rumah (Suhendro, 2020); serta penggunaan video (video guru mengajar di kelas) (Wakhidah \& Umah, 2020). Whatsapp dan Zoom sebagai aplikasi utama untuk mengadakan proses pembelajaran; sedangkan assesmen dan evaluasi dilakukan dengan mengamati respon dan perilaku anak selama belajar Zoom dan mereka juga melakukan home visit untuk memfasilitasi anakanak yang tidak dapat mengikuti kelas (Yuli Tri Andini, 2020) (Hutami \& Nugraheni, 2020).

\section{Metode Penelitian}

Metode penelitian pengembangan digunakan dalam penelitian ini. Secara garis besar langkah metode tersebut terdiri atas tiga kegiatan pokok; yaitu mendesain produk, memproduksi, dan mengevaluasi. Tahap perancangan meliputi: (a) Mengidentifikasi dan menentukan tujuan, sasaran, materi dan pendukung komponen; (b) Tahap produksi meliputi mengumpulkan dan mengkompilasi bahan-bahan produk awal, dan mengujinya; dan (c) Evaluasi (Purnama, 2016).

Setelah memperhitungkan kebutuhan penelitian, tahapan penelitian tersebut dimodifikasi menjadi empat tahap, yaitu tahap perencanaan, tahapa produksi, tahap penerapan, dan tahap evaluasi.

Tahap perancangan, meliputi menyusunan urutan pembelajaran membaca, menentukan materi ajar membaca, menginventarisasi tembang yang sudah ada dan melengkapinya, dan menentukan bentuk media pembalajaran; percangan dilaksanakan pada tanggal 07-14 Juli 2021.

Tahap produksi meliputi menentukan urutan pembelajaran membaca, melatih guru nembang tembang-tembang, membuat video dan alat peraga yang dilaksanakan pada tanggal 24-31 Juli 2021.

Video berisi pengantar yang berisi salam dan pengantar yang berisi apersepsi, guru menjelaskan tentang lagu/tembang yang akan diberikan pada anak, guru menjelaskan cara belajar membaca dengan tembang kepada orang tua, guru memberi contoh tembang secara keseluruhan sambil menun jukan alat peraga, guru mengajak siswa dan orang tua nembang perbaris, guru mengajak siswa dan orang nembang keseluruhan, guru mempersilahkan anak dan orang tua nembang berulang-ulang hingga hafal.

Tahap Uji coba pertama dilaksanakan pada hari sabtu tanggal 7 Agustus 2021 Pada uji coba pertama orang tua diberi penjelasan dan cara nembang tembang $\mathrm{ABC}$, kemudian orang tua mengajarkannya kepada anak mereka masingmasing.

Pertemuan kedua dilaksanakan pada tanggal 14 Agustus 2021 Pada uji coba kedua orang tua diberi penjelasan dan cara nembang tembang PDB atau cara menghafal bentuk huruf. Setelah itu orang tua mengajarkannya kepada anak mereka masing-masing di rumah.

Pertemuan ketiga dilaksanakan pada tanggal 21 Agustus 2021 Pada saat ini orang tua diberi diberi penjelasan dan cara nembang tembang AIUEO atau cara membaca huruf. Setelah itu orang tua mengajarkannya kepada anak mereka masing-masing di rumah.

Pertemuan keempat dilaksanakan pada tanggal 28 Agustus 2021 Pada kesempatan itu orang tua diberi penjelasan dan cara nembang tembang NGEJA atau cara menggabung huruf. Setelah itu orang tua mengajarkannya kepada anak mereka masing-masing di rumah.

Pertemuan kelima dilaksanakan pada tanggal 4 September 2021. Dalam pembelajaran orang tua diberi penjelasan cara nembang pengayaan atau tembang-tembang yang digunakan untuk memperkaya perbendaharaan kata anak. Setelah 
itu orang tua mengajarkannya kepada anaknya di rumah.

Tahapan evaluasi, penyebaran kuesioner, pengumpulan data tanggapan orang tua dan menganalisisnya dan melaporkannya. Selain itu video pembelajaran juga diunggah pada YouTube untuk mendapatkan tanggapan dari masyarakat.

\section{Hasil Penelitian}

Hasil penelitian media pembelajaran membaca anak usia dini berbasis dolanan anak adalah sebuah model pembelajaran yang terdiri atas tembang cara menghafal huruf latin, tembang cara menghafal bentuk huruf latin, tembang cara melafalkan huruf hidup huruf latin, tembang cara merangkai huruf latin menjadi kata, dan tembang pengayaan atau penambahan perbendarahaan kata untuk anak usia dini di masa pandemi. Tembang-tembang tersebut merupakan tembang-tembang anak yang sudah ada (tembang ABC atau tembang cara menghafal huruf latin dan tembang-tembang pengayaan perbendaharaan kata (tembang anak Kidang Talun, tembang anak Sugeng Enjing, tembang anak Gajah Belang, dan lain-lain); sedangkan tembang lainnya baru; yaitu tembang cara menghafal bentuk huruf latin, tembang cara membaca huruf hidup, dan tembang cara merangkai huruf latin.

Penerapan tembang-tembang tersebut dalam pembelajaran, berdasarkan jawaban orang tua atas pertanyaan di kuesioner dapat ditampilkan dalam Tabel 1.

Hasil kuesioner tersebut dapat ditafsirkan sebagai berikut. Pertama peran orang tua sebagai pengganti guru, dari jawaban orang tua atas pertanyaan apakah anda dapat mengajarkan secara lancar dan apakah anda mengajarkan setiap hari

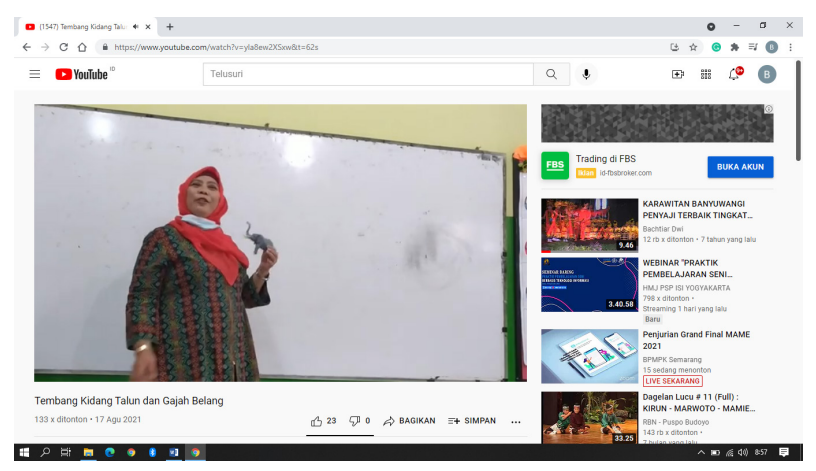

Gambar 1: Screenshot video pengayaan. prosentasi penjawab tidak lebih dari 50\%, artinya orang tidak dapat menggantikan peran guru sepenuhnya karena alasan orang tua bekerja atau alasan lainnya.

Tembang-tembang yang digunakan dalam model pembelajaran membaca ini diterima oleh sebagian besar anak dan orang tua. Hal itu terlihat dari jawaban seluruh pertanyaan kuesioner yang disebarkan kepada orang tua siswa untuk total prosentase jawaban senang sekali dan senang adalah 653,8 dan tidak senang dan sangat tidak senang 546,2 .

Tembang-tembang tersebut disenangi hampir lima puluh persen anak. Data jawaban orang tua atas pertanyaan kuesioner apakah anak anda senang dengan tembang tersebut adalah jawaban sangat senang $3,4 \%$, senang $42,6 \%$, tidak senang $38,3 \%$, dan sangat tidak senang $15,7 \%$. Hal ini mengindikasikan bahwa tembang-tembang yang digunakan dalam tembang tersebut disenangi anak.

Selain itu tembang-tembang tersebut juga dapat membangkitkan semangat belajar anak. Hal itu ditunjukkan dari data jawaban kesioner atas pertanyaan apakah anak anda menjadi lebih senang belajar membaca yang menjawab sangat

Tabel 1: Prosentase tanggapan kuesioner.

\begin{tabular}{|c|c|c|c|c|}
\hline Pertanyaan & SS & $S$ & TS & STS \\
\hline $\begin{array}{l}\text { 1. Apakah saudara mengajar tembang } \\
\text { secara lancar? }\end{array}$ & 2.6 & 40.9 & 44.3 & 12.2 \\
\hline $\begin{array}{l}\text { 2. Apakah setiap hari anda } \\
\text { mengajarkannya? }\end{array}$ & 1.8 & 33 & 52.2 & 13 \\
\hline $\begin{array}{l}\text { 3. Apakah anak anda senang dengan } \\
\text { tembang tersebut? }\end{array}$ & 3.4 & 42.6 & 38.3 & 15.7 \\
\hline $\begin{array}{l}\text { 4. Apakah anak anda dapat nembang } \\
\text { dengan mudah? }\end{array}$ & 1.7 & 18.3 & 55.7 & 24.3 \\
\hline $\begin{array}{l}\text { 5. Apakah syair tembang itu dipahami } \\
\text { anak? }\end{array}$ & 2.6 & 32.2 & 47.8 & 17.4 \\
\hline $\begin{array}{l}\text { 6. Apakah anak anda tertarik dengan } \\
\text { syair tembang itu? }\end{array}$ & 4.4 & 53.9 & 28.7 & 13 \\
\hline $\begin{array}{l}\text { 7. Apakah tembang ini memudahkan } \\
\text { belajar membaca? }\end{array}$ & 2,6 & 53 & 28.7 & 15.7 \\
\hline $\begin{array}{l}\text { 8. Apakah tembang menjadikan anak } \\
\text { anda senang membaca? }\end{array}$ & 4.7 & 42.6. & 36.5 & 16.5 \\
\hline $\begin{array}{l}\text { 9. Apakah anda setuju materi ini } \\
\text { diberikan seminggu sekali? }\end{array}$ & 7.8 & 58.3 & 22.6 & 11.3 \\
\hline $\begin{array}{l}\text { 10. Apakah anda setuju materi ini } \\
\text { dikembangkan? }\end{array}$ & 6.1 & 71.3 & 9.6 & 13 \\
\hline $\begin{array}{l}\text { 11. Apakah anda setuju materi ini } \\
\text { digabung dengan gamelan? }\end{array}$ & 14.8 & 71.3 & 11.3 & 2.6 \\
\hline $\begin{array}{l}\text { 12. Apakah anda setuju kegiatan gamelan } \\
\text { dan nembang dijadikan ciri khas } \\
\text { sekolah kita? }\end{array}$ & 11.2 & 73 & 9.6 & 6.2 \\
\hline Jumlah & 106 & 547.8 & 385.3 & 160.9 \\
\hline
\end{tabular}


senang $4,7 \%$, senang $42,6 \%$, tidak senang $36,5 \%$, dan sangat tidak senang $16,3 \%$.

Hal lain yang menjadi kelebihan model ini adalah syair tembang tersebut disenangi atau mendapat perhatian anak. Hal ini dibuktikan dengan jawaban orang tua atas pertanyaan kuesioner apakah anak tertarik dengan syair tembang itu yang menjawab sangat senang $4,4 \%$, senang $53,9 \%$, tidak senang $28,7 \%$, dan sangat tidak senang $13 \%$. Hal ini menunjukkan bahwa usaha guru membuat syair lucu agar disenangi anak berhasil

Tembang dolanan ini juga dapat diterima orang tua apabila dijadikan media pembelajaran dan bahkan digabung dengan gamelan dijadikan ciri pembelajaran di sekolahnya. Hal itu dibuktikan dengan pertanyaan apakah anda setuju materi ini diberikan seminggu sekali? Jawaban sangat setuju dan setuju mencapai 66,1\%; jawaban atas pertanyaan apakah anda setuju materi ini dikembangkan? yang menjawab sangat setuju dan setuju mencapi 77,4\%; jawaban sangat setuju dan setuju atas pertanyaan apakah anda setuju materi ini digabung dengan gamelan? mencapai $85,61 \%$; dan akumulasi jawaban sangat setuju dan setuju untuk jawaban pertanyaan Apakah anda setuju kegiatan gamelan dan nembang dijadikan ciri khas sekolah kita mencapai $74,2 \%$ ?

Selanjutnya, data tanggapan masyarakat. Data ini merupakan data respon masyarakat umum yang menanggapi media pembelajaran membaca ini melalui YouTube. Tanggapan tersebut berupa berapa kali masing-masing tembang tersebut dilihat, berapa jumlah masyarakat yang menanggapi baik atau positif dan bagaimana tanggapan mereka atas media pembelajaran dalam bentuk narasi atau kata-kata.

Tanggapan tentang berapa kali masing-masing tembang dilihat, berupa jumlah masyarakat yang menanggapi positif dan negatif. Tanggapantanggapan tersebut disajikan pada Tabel 2.

Tabel 2: Tanggapan masyarakat atas media pembelajaran.

\begin{tabular}{lccc}
\hline No Jenis Tembang & Dilihat & $\begin{array}{c}\text { Respon } \\
\text { Positif }\end{array}$ & $\begin{array}{c}\text { Respon } \\
\text { Negatif }\end{array}$ \\
\hline 1. Tembang belajar menghafal huruf & 201 & 73 & 0 \\
2. Tembang menghafal bentuk huruf & 209 & 66 & 0 \\
3. Tembang belajar membaca vokal & 156 & 47 & 0 \\
4. Tembang belajar menggabung huruf & 185 & 57 & 0 \\
5. Tembang pengayaan kata & 114 & 20 & 0 \\
\hline
\end{tabular}

Data tersebut dapat diteafsirkan pertama bahwa tidak setiap kali masyarakat melihat media pembelajaran ini memberi respon dan kedua semua masyarakat yang menanggapinya memberi tanggapan baik. Tanggapan masyarakat dapat ditafsrikan sebagai berikut. Pertama tanggapan yang memberi dorongan untuk melanjutkan. Contoh semangat, sukses, bagus, lanjutkan, mantul, oke. Kedua tanggapan yang menilai model ini bagus, misalnya mantul (mantap betul) terus, sangat bagus, membantu ortu selama belajar di rumah, bagus kreatif, semangat terus, semangat luar biasa membantu orang tua mengajar anaknya, inspiratif, cara menggingat huruf cepat.

Tanggapan ketiga menilai ide atau gagasan, yaitu semangat belajar, kreatif, semakin mudah belajar dan semangat, bagus, sangat bagus, memotivasi anak belajar, huruf vokal ditunjukkan lebih bagus, sangat bagus mudah diingat, keren, semangat untuk generasi penerus, kok nggak pakai bahasa Jawa pengantarnya, semangat perlu dicontoh, menjadi motivasi saya, semangat sukses selalu, jadi inspirasi. Dan yang terakhir adalah saran dari masyarakat, misalnya bahasa pengantarnya menggunakan bahasa Jawa agar sesuai dengan syair tembangnya dan penggunaan alat peraga kurang optimal.

\section{Pembahasan}

Berdasarkan diskusi hasil perancangan model pembelajaran membaca anak usia dini berbasis tembang anak di masa pandemi diterima masyarakat, namun hasilnya belum optimal. Hal itu terjadi karena pembatasan kegiatan sosial dan menjaga jarak sebagai usaha menghambat persebaran virus Covid-19 mengakibatkan orang tua harus menggantikan peran guru sebagai penyampai materi ajar kepada anaknya.

Hal tersebut tercermin pada jawaban atas pertanyaan apakah anda mengajar setiap dan apakah anda mengajar secara lancar yang menjawab tidak setuju dan sangat tidak setuju mencapai lebih dari enam puluh persen. Permasalahan tersebut, berdasarkan wawancara dengan guru, tidak terjadi ketika pembelajaran secara luring. Suasana belajar dengan teman, belajar sambil bermain yang selalu 
diciptakan guru maupun aspek profesionalitas guru adalah jawabannya.

Meskipun demikian tim penyusun media pembelajaran telah berhasil membuat model pembelajaran membaca berbasis tembang anak sesuai tujuannya. Tembang-tembang tersebut disenangi anak, mendorong mereka belajar membaca, suasana pembelajaran lebih semarak dan menyenangkan. Apabila hal ini diterapkan dalam pembelajaran yang berlangsung secara simultan dapat meningkatkan kualitas pendidikan, khususnya pembelajaran membaca anak usia dini. dengan demikian upaya meningkatkan kemampuan membaca generasi penerus bangsa dapat dicapai.

Keberhasilan tersebut karena beberapa faktor. Pertama pemilihan tembang anak sebagai pembelajaran merupakan hal yang tepat. Tembang anak yang melodinya sederhana dan sesuai tingkat perkembangan kejiwaan anak tersebut menjadikan suasana belajar lebih nyaman. Hal ini sesuai teori yang telah dibahas di bagian awal artikel ini bahwa musik membuat susana pembelajaran lebih menyenangkan, sedangkan penggunaan irama untuk menghafal kalimat dapat memudahkan anak belajar menghafal cara-cara membaca berbasis tembang anak.

Proses pembalajaran membaca berbasis tembang anak di masa pandemi ini mengalami kendala. Kendala tersebut adalah proses pembelajaran yang tidak optimal akibat peran guru menyampaikan materi ajar digantikan orang sangat tidak menguntungkan. Selain itu pembatasan kegiatan masyarakat yang tidak memperkenankan berkrumun menjadikan proses pembelajaran tersebut tidak sesuai dengan prinsip belajar sambil bermain. Pada pembelajaran ini pergerakan anak dibatasi sehingga mereka merasa tidak nyaman

Meskipun demikian, dari hasil diskusi dengan guru-guru di sekolah, permasalahan tersebut akan pulih ketika proses pembelajaran sudah diijinkan secara luring. Dalam pembelajaran luring yang memungkinkan anak bertemu dengan guru dan teman-teman menjadikan suasana pembelajaran lebih menyenangkan. Selanjutnya, apabila model pembelajaran membaca tersebut diterapkan dalam kondisi demikian, akan lebih berhasil dibanding pembelajaran daring. Selain itu kemampuan guru menyampaikan materi ajar yang disenangi anak merupakan faktor lain yang mendorong keberhasilan pembalajaran membaca berbasis tembang anak ini.

\section{Kesimpulan}

Tujuan utama penelitian yang ingin meningkatkan kualitas pembelajaran membaca di jenjang pendidikan prasekolah berbasis tembang anak terbukti dapat mendorong anak belajar membaca telah sesuai dengan tujuannya. Penerapannya dalam masa pandemi mengakibatkan dampkanya belum optimal, karena peran guru yang digantikan orang adalah sebabnya.

Model tersebut juga diterima oleh masyarakat dan orang tua menyetujui kegiatan itu dikembangkan dan dijadikan kegiatan pokok sekolah, sedangkan masyarakat menilai perancangan model pembelajaran membaca tersebut dari sisi kreativitasnya, inovasinya, dan dapat menginspirasi mereka, menginspirasi pengajar-pengajar atau guru-guru lain.

Permasalahan dampak yang belum optimal akibat pandemi akan teratasi dengan sendiri ketika pandemi sudah berakhir. Proses pembelajaran yang memungkinkan siswa dapat berinteraksi dengan guru dan teman mereka memungkinkan optimlisasi proses pembelajaran tersebut, termasuk di dalamnya penerapan model pembelajaran membaca berbasis tembang anak ini.

\section{Kepustakaan}

Bakar, Z. (2016). Pemanfaatan Lagu sebagai Implementasi Model Pakem pada Jenjang Pendidikan Anak Usia Dini dan Sekolah Dasar. EduHumaniora | Jurnal Pendidikan Dasar Kampus Cibiru, 3(2). https://doi. org/10.17509/eh.v3i2.2812

Constantin, F. A. (2015). Emotional Effects of Music Therapy on Children with Special Needs. Journal Plus Education, XII (Special Issue), 178-183.

Drossinou-korea, M., \& Fragkouli, A. (2016). Emotional Readiness and Music Therapeutic Activities. Journal of Research in Special 
Educational Needs, 16(1997). https://doi. org/10.1111/1471-3802.12305

Hewi, L., \& Shaleh, M. (2020). Refleksi Hasil PISA

(The Programme for International Student Assesment): Upaya Perbaikan Bertumpu pada Pendidikan Anak Usia Dini). Jurnal Golden Age, 4(01), 30-41. https://doi.org/10.29408/ jga.v4i01.2018

Hutami, M. S., \& Nugraheni, A. S. (2020). Metode Pembelajaran melalui Whatsapp Group sebagai Antisipasi Penyebaran Covid-19 pada AUD di TK ABA Kleco Kotagede. PAUDIA, 9(1), 126-130.

Indria, V. P., Sumarsih, \& Agustriana, N. (2017). Meningkatkan Kemampuan Membaca Permulaan melalui Metode Membaca Glenn Doman pada Anak Kelompok A PAUD Sambela Kota Bengkulu. Jurnal Ilmiah Potensia, 2(2), 95-100.

Istiyani, D. (2014). Model Pembelajaran Membaca Menulis Menghitung (Calistung) pada Anak Usia Dini di Kabupaten Pekalongan. Jurnal Penelitian, 10(1). https://doi.org/10.28918/ jupe.v10i1.351

Miranti, I., Engliana, \& Hapsari, F. S. (2015). Penggunaan Media Lagu Anak-Anak dalam Mengembangkan Kemampuan Kosakata Bahasa Inggris Siswa di PAUD. Jurnal Ilmiah Kependidikan, II(No. 2 Juli), 167-173.

Munawaroh Epriliani Aminah, \& Nisa, A. F. (2016). Strategi Mengusik (Mengeja dengan Musik) Cara Cepat Belajar Membaca Permulaan di Sekolah Dasar. AL-BIDAYAH: Jurnal Pendidikan Dasar Islam, 8(2).

Musfiroh, T. (2007). Permasalahan Membaca dan Menulis di KB dan TK. Jurnal Penelitian Humaniora, 12(2), 106-126.

Pramana, C. (2020). Pembelajaran Pendidikan Anak Usia Dini (PAUD) di Masa Pandemi Covid-19. Indonesian Journal of Early Childhood: Jurnal Dunia Anak Usia Dini, 2(2), 115-124. https://doi.org/10.35473/ ijec.v2i2.557

Purnama, S. (2016). Metode Penelitian dan Pengembangan (Pengenalan untuk Mengembangkan Produk Pembelajaran Bahasa Arab). LITERASI (Jurnal Ilmu
Pendidikan), 4(1), 19. https://doi. org/10.21927/literasi.2013.4(1).19-32

Raharja, B. (2021). Pembelajaran Dolanan Jawa Berbasis Pilar-pilar Pendidikan bagi Anak Usia Dini. Resital: Jurnal Seni Pertunjukan, 21(3), 150-162. https://doi.org/10.24821/resital. v21i3.4611

Rahmawati, N. R., Septiana, N. Z., \& Masitoh, F. (2019). Proceeding of International Conference on Islamic Education: Challenges in Technology and Literacy Faculty of Education and Teacher Training, Universitas Islam Negeri Maulana Malik Ibrahim Malang Pola Pengasuhan Orangtua Milenial. In Proceeding of International Conference on Islamic Education: Challenges in Technology and Literacy Faculty of Education and Teacher Training, Universitas Islam Negeri Maulana Malik Ibrahim Malang.

Ratminingsih, N. M. (2016). Efektivitas Media Audio Pembelajaran Bahasa Inggris Berbasis Lagu Kreasi di Kelas Lima Sekolah Dasar. JPI (Jurnal Pendidikan Indonesia), 5(1), 27. https://doi.org/10.23887/jpi-undiksha. v5i1.8292

Retnoningsih, D. A. (2019). Pembelajaran Literasi Berbasis Musik dan Lagu Anak terhadap Kemampuan Bahasa Siswa Sekolah Dasar. Jurnal Dialektika Jurusan PGSD, 9(2), 196209.

Rosmiati, A. (2014). Teknik Stimulasi dalam Pendidikan Karakter Anak Usia Dini melalui Lirik Lagu Dolanan. Resital: Jurnal Seni Pertunjukan, 15(1), 71-82. https://doi. org/10.24821/resital.v15i1.801

Simpson, K., \& Keen, D. (2011). Music Interventions for Children with Autism: Narrative Review of the Literature. J Autism Dev Disord, 41(January 2011), 1507-1514. https://doi.org/10.1007/s10803-010$1172-y$

Suhendro, E. (2020). Strategi Pembelajaran Pendidikan Anak Usia Dini. GOLDENAGE Jurnal Ilmiah Tumbuh Kembang Anak Usia Dini, 5(September), 133-140.

Thompson, G. A., \& Mcferran, K. S. (2015). Music Therapy with Young People Who have 
Profound Intellectual and Developmental Disability: Four Case Studies Exploring Communication and Engagement within Musical Interactions. Journal of Intellectual \& Developmental Disability, 40(1), 1-11.

Tjoe, J. L. (2013). Peningkatan Kemampuan Membaca Permulaan melalui Pemanfaatan Multimedia. Jurnal Pendidikan Usia Dini, 7(1), 17-48. Retrieved from http://pps.unj. ac.id/journal/jpud/article/view/31

Umroh, I. L. (2019). Peran Orang Tua dalam Mendidik Anak Sejak Dini Secara Islami di Era milenial 4.0. Talim: Jurnal Studi Pendidikan Islam, 2(2), 208-225. Retrieved from http://e-jurnal.unisda.ac.id/index.php/ talim/article/view/1644

Wakhidah, E. W., \& Umah, F. M. (2020). Penerapan Video Pembelajaran Daring Anak Usia Dini pada Masa Pandemi Covid-19 Pertama Kali di Indonesia. Al-Athfaal: Jurnal Ilmiah
Pendidikan Anak Usia Dini, 3(2), 140-160. Widaningsih, T. (2019). Revolusi Industri 4.0 dan Pendidikan Anak Usia Dini untuk Generasi Alfa: Sebuah Telaah. In Prosiding Seminar Nasional Pendidikan FKIP (Vol. 2, pp. 318319).

Yuli Tri Andini, M. D. W. (2020). Pelaksanaan Pembelajaran Daring pada Masa Pandemi Covid-19 diTKBIAS Yogyakarta. Tarbiyatuna: Kajian Pendidikan Islam, 4(2), 206-216.

Yulia, L. N. (2013). Pengenalan Membaca bagi Anak Usia Dini dengan Pendekatan Beyond Center Circle Time(Bcct) Di Taman KanakKanak Islam Al-Azhar Kota Bukittinggi. Spektrum pls, 1(5), 119-130.

Yuliatun, Y. (2018). Belajar Membaca bagi Anak Usia Dini: Stimulasi Menumbuhkan Minat Baca Anak. ThufuLA: Jurnal Inovasi Pendidikan Guru Raudhatul Athfal, 2(1), 127. https://doi.org/10.21043/thufula.v2i1.4269 